\title{
THE INFLUENCE OF CONTAMINANTS DURING THE FIRING OF INKS
}

\author{
A.J.M. VAN GORP and J.H.C. VAN MOURIK \\ N.V. Philips' Gloeilampenfabrieken, Eindhoven, The Netherlands \\ (Received June 5, 1981; in final form June 26, 1982)
}

\begin{abstract}
During firing of resistor materials the resistance is influenced by gaseous contaminants and by compounds given off by other pastes. Nearly all inorganic salts which are slightly volatile at the firing temperature, and some rather stable organic materials influence the resistor properties. Halogenated materials are the most important and the higher ohmic series the most sensitive.

For aluminium conductors a very high sensitivity to fluorinated and chlorinated compounds has been found but in this case organic compounds have no influence.
\end{abstract}

\section{INTRODUCTION}

The fired resistor properties of thick film resistors and conductors are influenced by process parameters, such as the time/temperature relationship of the furnace and by contaminants, which are present during firing in the furnace or which are absorbed before firing starts.

In this last case really large deviations from normal values can arise, even such that the whole batch falls outside the specifications, being in our case a limit of about $\pm 25 \%$. The higher ohmic resistors are most sensitive to these kind of materials.

In general this subject has not been dealt with in the literature. Lynch ${ }^{1}$ has done a critical study on thick film resistors, in which he determined the influence of the quality of the compressed air in the furnace.

Next to that it is generally known that halogenated hydrocarbons can have a detrimental effect. Only Dupont ${ }^{2}$ has given some figures. They found an influence of only $100 \mathrm{ppm}$ trichloroethylene and of more than $1000 \mathrm{ppm}$ trichloroethane on their 1300 series resistors, while thinners had only a minor influence.

In our factory a large influence of only small amounts (some ppm) Freon TF in the atmosphere on all resistor pastes and on aluminium paste has been found.

Next to these air contaminants it is possible that chemical decomposition products influence the properties of other pastes. For instance it was found that some dielectric and glass pastes changed the properties of cofired resistors, more especially if relative large amounts of these pastes are present in the furnace.

In order to be informed which compounds are responsible for this influence a test has been set up. The emphasis was laid on those constituents which are transported through the gaseous phase but originate from other substrates. As vehicles we used some resistor and aluminium pastes primarily.

\section{EXPERIMENTAL DESIGN}

A batch of numbered substrates were printed in a reproducible way on an automatic de Haert printer and each tenth substrate was fired in random sequence in a belt furnace at $850^{\circ} \mathrm{C}$. The resistance of each resistor was measured and the mean and variation coeffi- 
cient calculated for the whole series. In this manner the nominal value of each other substrate is known and a test sample which deviated more than $10 \%$ from the mean was considered as influenced.

For the execution of the tests the furnace was stabilized by sending through clean substrates. On one substrate a known amount of the material under test was applied and this one was preceded by 1 and followed by 1 to 20 test samples (Figure 1) and fired. For the application of small amounts of substance $(<10 \mathrm{mg})$ on a resistor a microdispenser with a solution of known concentration was used. After firing the resistance and sometimes the HTCR - of each resistor was measured.

In order to get an insight into the quantities which affect only one resistor, a known amount of substance - as solution - was applied on a dried resistor and fired in the standard manner.

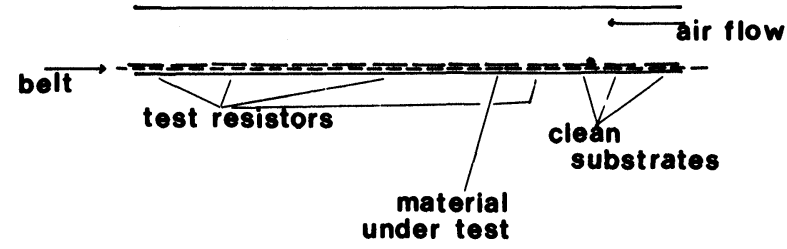

FIGURE 1 Sequence of substrates during firing.

TEST CIRCUITS
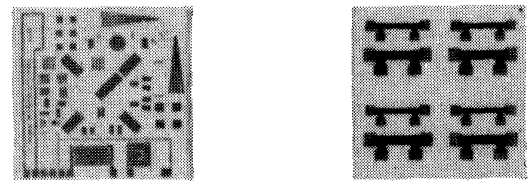

AL paste

R paste

FIGURE 2 Testpatterns used.

\section{TEST CONDITIONS}

3.1 Pastes:

$\begin{array}{ll}\text { Al paste } & \text { Engelhard T } 1486 \\ & \text { Engelhard T } 2848 \\ & \text { Demetron 67900026 } \\ \text { Demetron } 67900008 \\ \text { R paste } & \text { DP 1361 } \\ & \text { DP 1341 } \\ & \text { DP 1321 } \\ & \text { ESL 2914 }\end{array}$

3.2 Pattern:

see Figure 2. 
3.3 Printer Settings:

de Haert printer

Pressure 5-6 N/cm

Speed $10 \mathrm{~cm} / \mathrm{s}$

Squeegee $65^{\circ} \mathrm{Sh}$, under $45^{\circ}$

Stainless steel screens, 200 mesh.

\subsection{Drying:}

$15 \mathrm{~min}$. at $120^{\circ} \mathrm{C}$.

\subsection{Firing:}

Watkins and Johnson furnace, $4 \mathrm{inch}, 50 \mathrm{~min}$. profile with $8 \mathrm{~min}$. dwell time at $850^{\circ} \mathrm{C}$.

\subsection{Measuring:}

Resistance with Philips Digital r.m.s. multimeter PM 2526.

\section{RESULTS}

With our vapour phase tests in general only a small influence was detected on the sample just before the substrate with the material under test and a decreasing influence on those after it, which gave us the indication that the stream of air was definitely in the reverse direction of the belt.

From Table I and Figure 3 it is clear that the resistance value of an unknown sample

TABLE I

Reproducibility of printing resistors (DP 1361) in one series.

\begin{tabular}{llll}
\hline & & $\mathrm{R} 1$ & $\mathrm{R} \mathrm{2}$ \\
\hline $\mathbf{n}=$ & 21 & 21 \\
$\overline{\mathbf{x}}=$ & $4,44 \mathrm{M} \Omega$ & $10,55 \mathrm{M} \Omega$ \\
$\sigma$ & $0,21 \mathrm{M} \Omega$ & $0,48 \mathrm{M} \Omega$ \\
$\mathrm{C} . \mathrm{V} .=$ & $4,6 \%$ & $4,6 \%$ \\
\hline
\end{tabular}

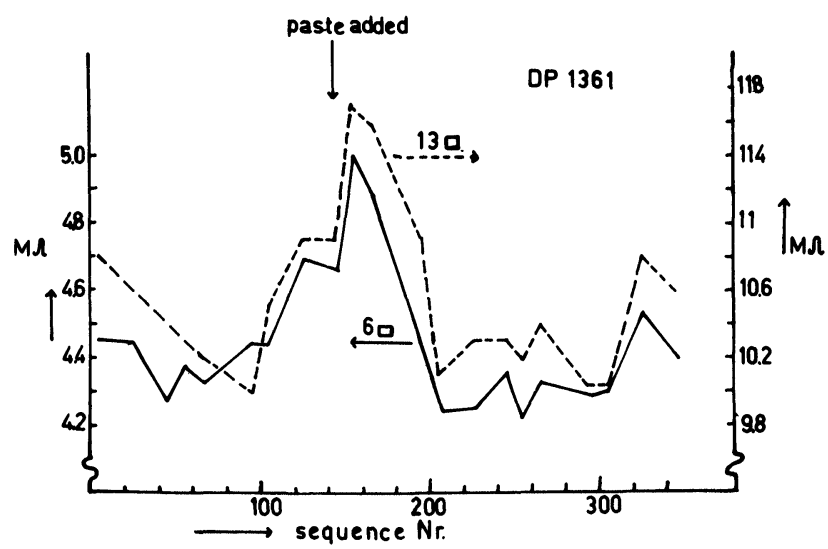

FIGURE 3 Resistance of printed substrates in dependence of sequence. 
TABLE II

The influence of $20 \mu \mathrm{g}$ salt on DP 1341 (applied as solution on a resistor)

\begin{tabular}{llllll}
\hline Salt & $\mathrm{R} \%$ & $\mathrm{Salt}$ & $\mathrm{R} \%$ & $\mathrm{Acid}$ & $\mathrm{R} \%$ \\
\hline $\mathrm{KF}$ & -20 & $\mathrm{Na}_{2} \mathrm{SO}_{4}$ & -30 & $\mathrm{HF}$ & $<5$ \\
$\mathrm{NaF}$ & -30 & $\mathrm{Na}_{2} \mathrm{~S}_{2} \mathrm{O}_{3}$ & -30 & $\mathrm{HAc}$ & $<5$ \\
$\mathrm{KCl}$ & -20 & $\mathrm{NaNO}_{3}$ & -35 & $\mathrm{HNO}_{3}$ & $<5$ \\
$\mathrm{NaCl}$ & -15 & $\mathrm{Na}_{2} \mathrm{CO}_{3}$ & -40 & $\mathrm{H}_{2} \mathrm{SO}_{4}$ & -10 \\
$\mathrm{KI}$ & -30 & & & $\mathrm{H}_{3} \mathrm{PO}_{4}$ & +10 \\
\hline
\end{tabular}

within a series of printed substrates can be predicted within $5 \%$. As a limit for considering an effect as a positive one a change $10 \%$ compared with the reference was taken.

A survey of the qualitative and quantitative results with the $R$ pastes is given in Tables II to VIII and those concerning the aluminium pastes are found in Table VIII.

\section{DISCUSSION OF THE RESULTS}

From Table II we can see that cofiring of only $20 \mu \mathrm{g}$ inorganic material on a resistor (of $2-3 \mathrm{mg}$ ) leads to a decrease of the resistance by $20-40 \%$. So an addition of only $0.5-5 \%$ of the weight of the resistive material can give considerable change in resistivity. Which material has been added is not very important: each one gives about the same change. The addition of a conducting material only brings forward this effect. Some acids have no influence because they are volatilized before reaction can take place.

Those gaseous phase experiments which have given an effect on the 4 resistive materials used are given in Table III. In all, these cases $5 \mathrm{mg}$ of inorganic material was used, part of it being still present after the firing cycle.

TABLE III

The influence of $5 \mathrm{mg}$ salt applied on a separate substrate

\begin{tabular}{|c|c|c|c|c|}
\hline Contaminant & DP 1361 & DP 1341 & DP 1321 & ESL 2914 \\
\hline $\begin{array}{l}\mathrm{KF} \\
\mathrm{BiF}_{3}\end{array}$ & $\begin{array}{l}++ \\
++\end{array}$ & ++ & $+*$ & $++*$ \\
\hline $\begin{array}{l}\mathrm{NH}_{4} \mathrm{Cl} \\
\mathrm{NaCl} \\
\mathrm{KCl} \\
\mathrm{NiCl}_{2} \\
\mathrm{ZnCl}_{2} \\
\mathrm{BaCl}_{2}\end{array}$ & $\begin{array}{l}+++ \\
+++ \\
+++ \\
+++ \\
+++ \\
++\end{array}$ & $\begin{array}{l}++ \\
+++ \\
+++ \\
+++ \\
++\end{array}$ & $\begin{array}{l}+ \\
+\end{array}$ & $\begin{array}{l}++ \\
+\end{array}$ \\
\hline $\mathrm{KBr}$ & +++ & +++ & + & 0 \\
\hline KI & +++ & +++ & $+*$ & $+*$ \\
\hline $\begin{array}{l}\mathrm{MoO}_{3} \\
\mathrm{Sn} / \mathrm{InO} \mathrm{x}\end{array}$ & $\begin{array}{l}+++ \\
++\end{array}$ & +++ & & \\
\hline $\begin{array}{l}\mathrm{H}_{2} \mathrm{SO}_{4} \\
\mathrm{H}_{3} \mathrm{PO}_{4} \\
\mathrm{NaOH}^{2}\end{array}$ & $\begin{array}{l}+++ \\
+++\end{array}$ & $\begin{array}{l}+++ \\
+++ \\
++\end{array}$ & $\begin{array}{l}0 \\
0\end{array}$ & $\begin{array}{l}0 \\
++*\end{array}$ \\
\hline
\end{tabular}

$\begin{array}{ll}* & \text { means change positive } \\ 0 & \text { means influence }<5 \% \\ + & \text { means influence } 5-10 \% \\ ++ & \text { means influence } 10-25 \% \\ +++ & \text { means influence }>25 \%\end{array}$


An effect can only be expected if the material can be transported via the gaseous phase in the critical temperature range. Indeed no effect could be observed with very volatile materials, such as $\mathrm{HF}, \mathrm{HCl}$ and $\mathrm{HNO}_{3}$ or with substances which have a negligable vapour pressure at $850^{\circ} \mathrm{C}$, such as many oxides $\left(\mathrm{CdO}, \mathrm{B}_{2} \mathrm{O}_{3}, \mathrm{PbO}\right)$ carbonates $\left(\mathrm{Na}_{2} \mathrm{CO}_{3}, \mathrm{CaCO}_{3}\right)$, fluorides $\left(\mathrm{LiF}, \mathrm{BaF}_{2}\right)$ and sulfates $\left(\mathrm{Na}_{2} \mathrm{SO}_{4}\right)$.

From Table III and IV, it can be seen that, within one series of pastes the greatest effects occur with the higher ohmic ones. Next to that ESL 2914, based on lead ruthenate, differs much from DP 1341 , based on bismuthruthenate. If the quantity of inorganic material (Table IV) is under a certain threshold (which is for $\mathrm{KCl} 0,5 \mathrm{mg}$ ) no effect is observed, but above that threshold an exponential increase can be seen.

Cofiring other pastes has no large influence, as should be expected, but DP 9061 and DP 5217 have a significant effect. However if many substrates, each with a harmless amount of paste are present in the furnace, effects will be distinguishable with many pastes.

From Table $\mathrm{V}$ the effect of the vapour pressure can be seen. Some halogenides which

TABLE IV

The quantitative influence of some inorganic materials and pastes on resistor pastes

\begin{tabular}{|c|c|c|c|c|c|}
\hline \multicolumn{2}{|c|}{ Contaminant } & \multirow{2}{*}{$\begin{array}{l}\text { DP } 1361 \\
-2 \% \\
-55 \% \\
-82 \% \\
-97 \% \\
-53 \% \\
-44 \%\end{array}$} & \multirow{2}{*}{$\begin{array}{l}\text { DP } 1341 \\
+6 \% \\
-24 \% \\
-62 \% \\
-48 \% \\
-36 \% \\
-29 \%\end{array}$} & \multirow{2}{*}{$\begin{array}{c}\text { DP 1321 } \\
0 \% \\
+11 \% \\
-6 \% \\
-4 \% \\
-4 \% \\
+6 \%\end{array}$} & \multirow{2}{*}{$\begin{array}{l}\text { ESL 2914 } \\
+2 \% \\
+20 \% \\
-16 \% \\
-6 \% \\
+2 \% \\
+8 \%\end{array}$} \\
\hline $\begin{array}{l}\mathrm{NaF} \\
\mathrm{KF} \\
\mathrm{NaCl} \\
\mathrm{KCl} \\
\mathrm{KBr} \\
\mathrm{KI}\end{array}$ & $5 \mathrm{mg}$ & & & & \\
\hline $\begin{array}{l}\text { DP } 9061 \\
\text { DP } 9911 \\
\text { DP } 5217 \\
\text { DP } 9101 \\
\text { DP } 8190 \\
\text { DP } 9950 \\
\text { DP } 8315 \\
\text { DP } 1361\end{array}$ & $1000 \mathrm{mg}$ & $\begin{array}{l}-10 \% \\
-5 \% \\
-14 \% \\
+\quad 2 \% \\
-4 \% \\
+3 \% \\
+4 \% \\
-3 \%\end{array}$ & $\begin{array}{l}-7 \% \\
-5 \% \\
-5 \% \\
+\quad 3 \% \\
+2 \% \\
-8 \% \\
-6 \% \\
0 \%\end{array}$ & $\begin{array}{r}-4 \% \\
-10 \% \\
+5 \% \\
-8 \% \\
-12 \% \\
-2 \%\end{array}$ & $\begin{array}{r}0 \% \\
-5 \% \\
+11 \% \\
-3 \% \\
-6 \% \\
-6 \% \\
-3 \%\end{array}$ \\
\hline $\begin{array}{l}\mathrm{KCl} \\
\mathrm{KCl} \\
\mathrm{KCl} \\
\mathrm{KCl} \\
\mathrm{KCl}\end{array}$ & $\begin{array}{l}0,1 \mathrm{mg} \\
0,2 \mathrm{mg} \\
0,5 \mathrm{mg} \\
1 \quad \mathrm{mg} \\
5 \quad \mathrm{mg}\end{array}$ & $\begin{array}{r}+2 \% \\
0 \% \\
-3 \% \\
-44 \% \\
-97 \%\end{array}$ & $\begin{array}{l}+2 \% \\
-1 \% \\
-6 \% \\
-30 \% \\
-48 \%\end{array}$ & $\begin{array}{l}-1 \% \\
-1 \% \\
-4 \% \\
-2 \% \\
-4 \%\end{array}$ & $\begin{array}{r}0 \% \\
1 \% \\
1 \% \\
1 \% \\
-5 \%\end{array}$ \\
\hline
\end{tabular}

TABLE V

The effect of some salts on DP 1341. The decrease of the resistance value is determined by the vapour pressure of the substance at $850^{\circ} \mathrm{C}$.

\begin{tabular}{llll}
\hline Salt & $\begin{array}{l}20 \mu \mathrm{g} \\
\text { (drop) }\end{array}$ & $\begin{array}{l}5 \mathrm{mg} \\
\text { (vapour) } \\
\%\end{array}$ & $\begin{array}{l}\text { vapour } \\
\text { pressure } \\
\mathrm{mg} \mathrm{Hg}\end{array}$ \\
\hline $\mathrm{NaF}$ & -30 & $<5$ & $<0,02$ \\
$\mathrm{NaCl}$ & -15 & -60 & 0,8 \\
$\mathrm{NaOH}$ & - & -20 & 5,4 \\
$\mathrm{KF}$ & -20 & -20 & 0,6 \\
$\mathrm{KCl}$ & -20 & -45 & 1,7 \\
$\mathrm{KBr}$ & - & -36 & 2,6 \\
$\mathrm{KI}$ & -30 & -29 & 5,8 \\
\hline
\end{tabular}


TABLE VI

Organic compounds which influence the resistance value

\begin{tabular}{ll}
\hline No effect & Effective \\
\hline volatile solvents & acetates \\
terpineol & stearic acid and salts \\
phatalate esters & soya lecithin \\
carbon & soya bean oil \\
ethylcellulose & paraffin wax \\
polyethylene & bees wax \\
polyvinylchloride & polyvinylacetate \\
prinar & teflon \\
\hline
\end{tabular}

TABLE VII

Effect of the amount of soya lecithin (vapour phase)

\begin{tabular}{rllll}
\hline & DP 1361 & DP 1341 & DP 1321 & ESL 2914 \\
\hline $10 \mathrm{mg}$ & $-7 \%$ & $-11 \%$ & $-17 \%$ & $-11 \%$ \\
$20 \mathrm{mg}$ & $-17 \%$ & $-18 \%$ & $-19 \%$ & $-15 \%$ \\
$50 \mathrm{mg}$ & $-16 \%$ & $-21 \%$ & $-27 \%$ & $-18 \%$ \\
$100 \mathrm{mg}$ & $-22 \%$ & $-26 \%$ & $-29 \%$ & $+128 \%$ \\
\hline
\end{tabular}

show the same change, when dosed as drop, show a different effect in the vapour phase primarily on basis of their vapour pressure.

Organic compounds too can influence the resistance value (Table VI). In general, high molecular weight substances, which decompose above $200-300^{\circ} \mathrm{C}$ and whose decomposition products contain reducing substances, are effective.

The mechanism however is different (Table VII).

In this case the effect depends not very much on the quantities and besides that the influences on the investigated pastes are comparable. The value of $+128 \%$ on ESL paste is unexplained.

As pastes contain relatively much organic materials, these are perhaps the most important.

If through some organic or inorganic material the resistivity changes, the TCR is changed too.

The results obtained with $\mathrm{Al}$ pastes have been gathered in Table VIII, from which can be seen that the sensitivity to $\mathrm{Na} / \mathrm{KF}$ or $\mathrm{Na} / \mathrm{KCl}$ is very large. Here resistivity increases a factor $10^{6}$.

From Figure 4 it can be seen that even $0,2 \mathrm{mg} \mathrm{NaF}$ has a significant effect and with higher quantities the change is larger and visible over a larger distance in the furnace. With $4 \mathrm{mg} \mathrm{NaF}$, substrates, $100 \mathrm{~cm}$ further on are already influenced. If a drop of solution is put on the printed line and fired, only $2 \mu \mathrm{g}$ of $\mathrm{NaF}$ or $10 \mu \mathrm{g} \mathrm{NaCl}$, being $0,01-0,1 \%$ of the metal, gave an infinite resistance with $T$ 1486. The other pastes are somewhat less sensitive, but $10 \mu \mathrm{g}$ of $\mathrm{NaF}$ gave in all cases infinite resistance.

In general T 1486 is somewhat more sensitive to all inorganic materials. This sensitivity, primarily to halogenated substances, can be explained by a change in structure of the metallization. If a contamination is present, the molten drops of aluminium flow together, presumably under the influence of the change in surface tension of the glass, to larger drops, which are expelled from the layer and are visible after cooling down. By this growth in drop size the contact resistance increases, leading even to loss of mutual contact. 


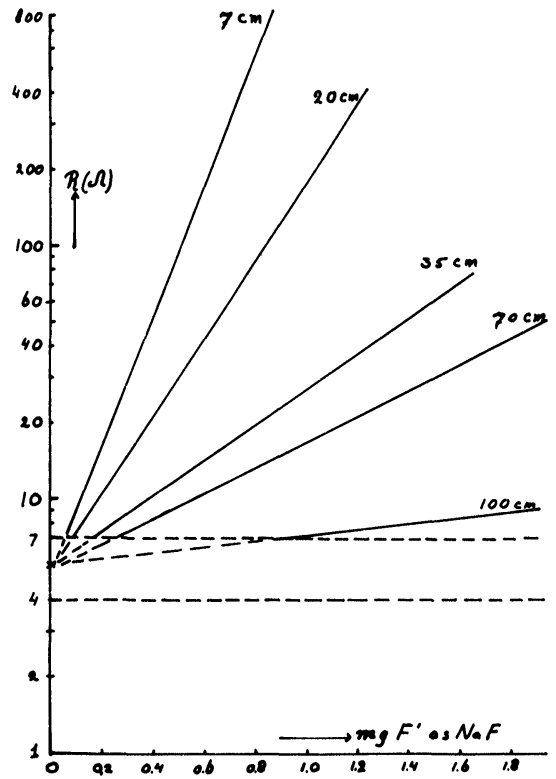

FIGURE 4 Influence of $\mathrm{NaF}$ on the resistance of $\mathrm{Al}$ pastes.

It is clear that these kinds of pastes are very sensitive to contamination of the furnace atmosphere by halogenated hydrocarbons.

No influence could be detected from organic materials, mentioned in Table VI, or from other pastes, except from DP $5217(\mathrm{R} \infty)$ which contains a fluoride. Even a layer of fired DP 5217 gives infinite resistances with $\mathrm{Al}$ pastes.

TABLE VIII

The effect of $5 \mathrm{mg}$ salt (vapour phase) on the resistivity of aluminium pastes (in $\Omega$ ).

\begin{tabular}{|c|c|c|c|c|}
\hline & T 1486 & $\begin{array}{l}\text { lhard } \\
\text { T } 2848\end{array}$ & 67900008 & $\begin{array}{l}\text { netron } \\
67900026\end{array}$ \\
\hline reference & 4 & 5 & 5 & 3 \\
\hline $\mathrm{LiF}$ & 35 & 33 & $\infty$ & 6 \\
\hline KF & $\infty$ & $\infty$ & $\infty$ & $\infty$ \\
\hline $\mathrm{NaF}$ & $\infty$ & $\infty$ & $\infty$ & $\infty$ \\
\hline $\mathrm{BaF}_{2}$ & 6 & 10 & 5 & 4 \\
\hline $\mathrm{KCl}^{*}$ & $\infty$ & 8 & $\infty$ & $\infty$ \\
\hline $\mathrm{NaCl}$ & $\infty$ & 5 & $\infty$ & $\infty$ \\
\hline $\mathrm{BaCl}_{2}$ & 4 & 8 & 5 & 3 \\
\hline $\mathrm{NiCl}_{2}$ & 5 & - & $\infty$ & - \\
\hline $\mathrm{KBr}$ & 16 & 7 & 9 & 7 \\
\hline KI & 7 & 4 & 7 & 3 \\
\hline $\mathrm{Na}_{2} \mathrm{SO}_{4}$ & 4 & 4 & 4 & 5 \\
\hline $\mathrm{Na}_{2} \mathrm{~S}_{2} \mathrm{O}_{3}$ & $\infty$ & - & $\infty$ & - \\
\hline $\mathrm{H}_{2} \mathrm{SO}_{4}$ & 81 & 4 & 5 & 30 \\
\hline $\mathrm{NaOH}$ & 4 & 6 & 5 & 3 \\
\hline DP 5217 & $\infty$ & $\infty$ & $\infty$ & $\infty$ \\
\hline
\end{tabular}

$\infty$ means $>20 \mathrm{M} \Omega$. 


\section{CONCLUSIONS}

It has been proven that inorganic materials (salts) do influence the resistive value and TCR of resistor pastes during cofiring, if these compounds are slightly volatile at $850^{\circ} \mathrm{C}$. An estimated vapour pressure of $0,01 \mathrm{~mm} \mathrm{Hg}$ is enough. This is the case for many halogenated compounds. The mechanism of interaction is presumably the adsorption of conducting material, by which the resistivity decreases, and so the higher ohmic pastes are the most sensitive.

Some higher molecular weight organic compounds show the same effect, however in this case a superficial reduction of $\mathrm{RuO}_{2}$ is more acceptable. All pastes, independent of sheet resistance and composition, show about the same sensitivity. As organic compounds are present in all pastes, this material in general will give the largest contribution. And among them soya lecithin is a prominent one.

Aluminium pastes are very sensitive to even $\mu$ g quantities of fluorides and chlorides, by which the surface tension equilibrium is changed, forming larger drops of $\mathrm{Al}$, loosening their mutual contact. If the resistivity is of prime importance all such contaminations must be excluded.

Next to these contaminations given off by pastes, a pollution of the furnace atmosphere with organic compounds, containing a halogen, phosphorus, or sulfur atom will undoubtedly lead to resistivity and TCR influences.

\section{REFERENCES}

1 J.F. Lynch, W. Cardone, E. Watje, "Critical study of furnace atmospheres for firing thick film resistors", Proc. 29th Electr. Comp. Conf., (1979).

2 Anon., Dupont Thick Film Newsline, Issue 2, (March 1977). 

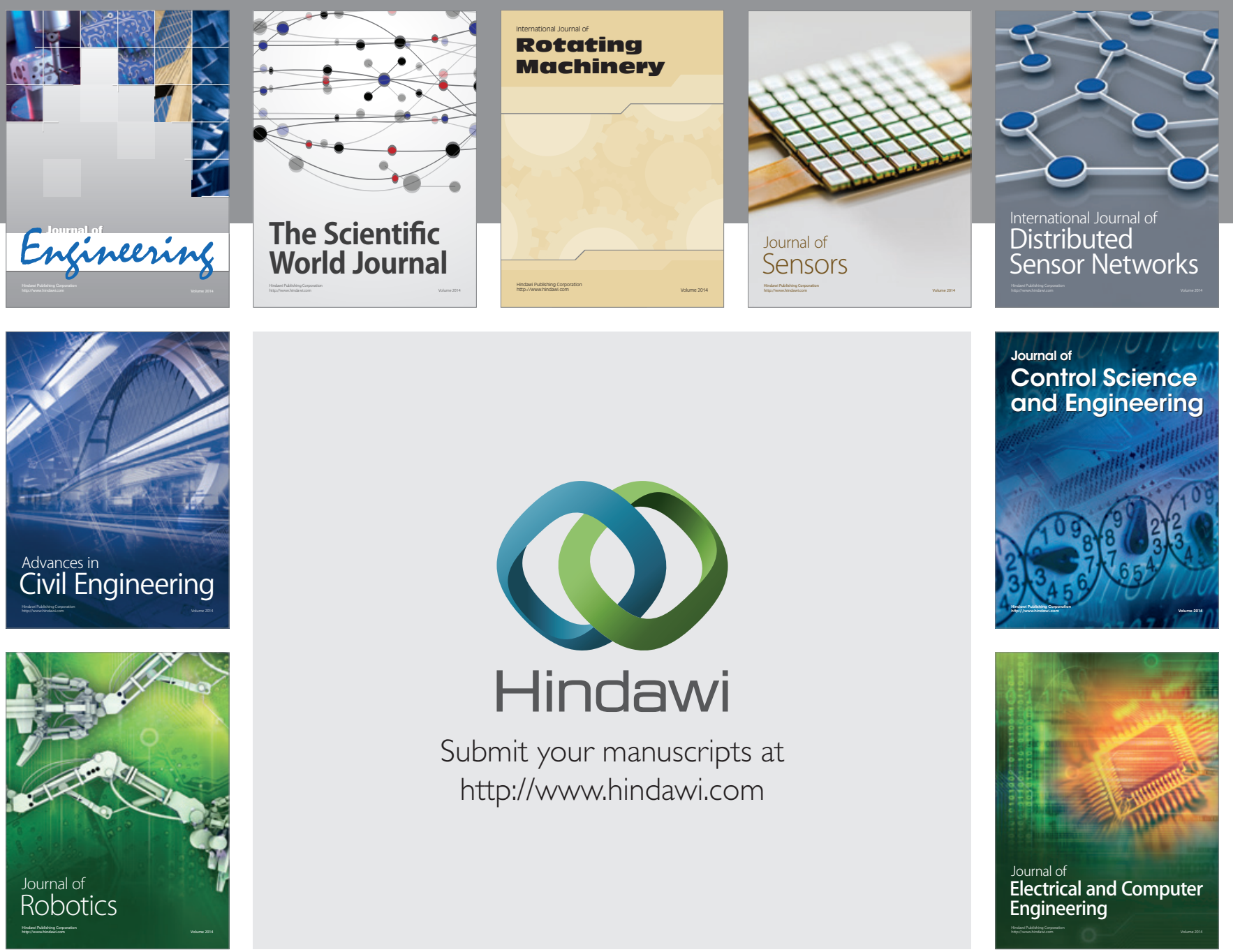

Submit your manuscripts at

http://www.hindawi.com
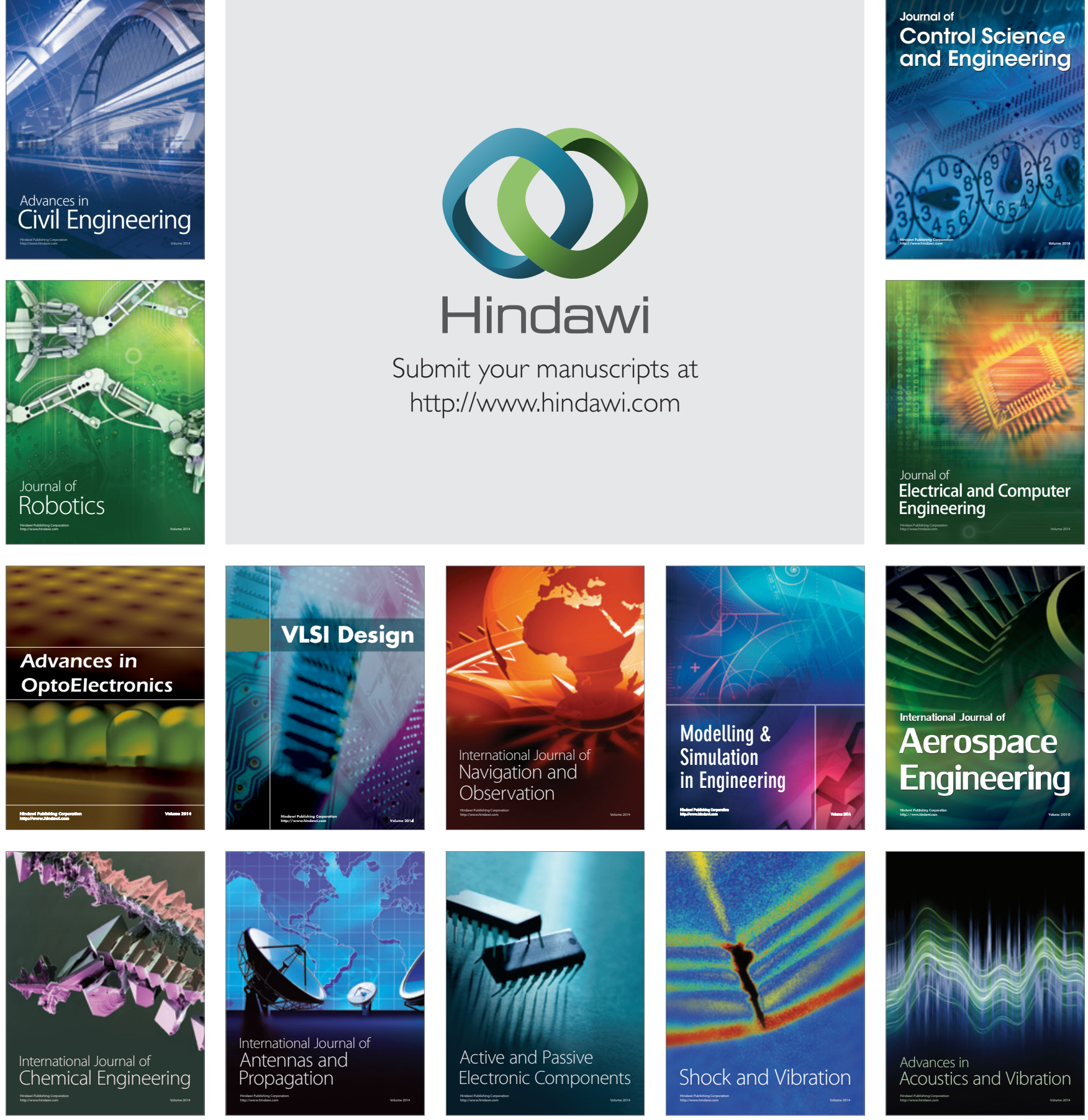